\title{
Molecular profiling of sweet cherry cultivars present in Chile using polymorphic microsatellite markers
}

\author{
Verónica Guajardo ${ }^{1}$, Carlos Muñoz ${ }^{2}$, and Patricio Hinrichsen ${ }^{3 *}$ \\ ${ }^{1}$ Centro de Estudios Avanzados en Fruticultura (CEAF), Las Parcelas 882, Sector Los Choapinos, Rengo, Chile. \\ ${ }^{2}$ Universidad de Chile, Facultad de Ciencias Agronómicas, Av. Santa Rosa 11315, Santiago, Chile. \\ ${ }^{3}$ Instituto de Investigaciones Agropecuarias, INIA La Platina, Av. Santa Rosa 11610, Santiago, Chile. \\ *Corresponding author (phinrichsen@inia.cl).
}

Received: 22 December 2020; Accepted: 18 March 2021; doi:10.4067/S0718-58392021000300326

\begin{abstract}
Sweet cherry (Prunus avium (L.) L.) is one of the most important fruit crops of temperate climates. In Chile, the actual planted area is over 42000 ha that produce over $260000 \mathrm{t}$ yearly. The accurate identification of sweet cherry cultivars is key for processes involved both in breeding new cultivars and along the production chain. In this study, we performed the molecular characterization of 87 sweet cherry genotypes cultivated in Chile, using nine microsatellite markers originally described for both peaches and sweet cherries. The analysis showed that 69 of these genotypes corresponded to unique cultivars, each harboring a unique allelic pattern. They could be differentiated using only five markers (BPPCT-037, BPPCT-039, BPPCT-040, PMS-30 and UCD-CH18). The remaining 19 genotypes could correspond to misidentified, mutated or even synonyms of the studied genotypes, since they have allelic patterns identical to one or more of the 69 individualized genotypes. Between 3 and 8 alleles per marker were identified, with a mean of 6 , while the expected heterozygosity over the nine polymorphic loci averaged 0.72, ranging from 0.59 in UDP96-001 to 0.78 in BPPCT-040. Phylogenetic and population structure analyses showed that most cultivars were grouped according to their country of origin or the breeding program from where they were released, being also coincident with their presumed pedigrees. These results are the basis for a fingerprinting protocol, based on microsatellite markers, for sweet cherry cultivars.
\end{abstract}

Key words: Cultivar identification, fingerprinting, germplasm, molecular markers, Prunus avium, SSR.

\section{INTRODUCTION}

The sweet cherry (Prunus avium (L.) L.) is one of the most important fruit crops of temperate climates, with a global yearly production (2019/2020) of almost 4 million metric tons, of which 260000 are produced in Chile, in about 42000 ha. This makes Chile the main exporter of this fruit to the world, with a year total export of 230000 metric tons (https://gain.fas.usda.gov/).

The species is a member of the Rosaceae family, subfamily Amygdaloideae, tribe Amygdaleae. It is a diploid species with a basic chromosome number of $8(x=8)$ and the diploid genome organized in a $2 n=2 x=16$ chromosomes (Iezzoni et al., 2017). Although cherries have been cultivated for more than 2000 years, cherry breeding started around the early 1800s, so some modern cultivars are just a few generations away from their early ancestors (Iezzoni et al., 1990). Breeding programs in Europe initially began by selecting particular landraces, which were used afterwards as parents (Quero-García, 2019). Seeds transported from Europe to North America started the production of this fruit in the New World, where important cultivars have been developed since the $19^{\text {th }}$ Century (Brown et al., 1996).

Corporative and private sweet cherry breeding programs have released numerous cultivars (Quero-García, 2019), which are planted at different locations, depending on their adaptation to particular sites. It has been suggested that only a 
limited number of genotypes has been used in breeding this species and, consequently, modern cultivars harbor a narrow genetic base. For instance, Choi and Kappel (2004) indicate that five founding genotypes were most commonly used as parents in North American breeding programs.

The correct identification of existing and new cultivars is an important challenge both for fruit production and for breeding new cultivars. Germplasm repositories, breeding programs and the commercialization of fruits and plants, require unequivocal identifications of cultivars to avoid the use of incorrect genotypes in crossings, to protect registered or patented cultivars, and to assure the propagation of true-to-type genotypes.

The use of molecular markers complements the traditional cultivar characterization based on morphological and/or phenological data, providing a genetic profile or fingerprinting of each individual. The use of this complement, enables the clarification of the origin of plant cultivars (Krmpot et al., 2020), standardization of planting material, protection of new cultivars by breeders' rights (Ru et al., 2015), and the study of the genetic relatedness of cultivars to keep the heterozygosity of the breeding populations (Yaroslav and Volkov, 2018).

Microsatellites or simple sequence repeats (SSRs) are among the most widely used molecular markers, due to their hypervariability, multiallelic nature, codominant inheritance, and reproducibility, (Kalia et al., 2011). Microsatellite identification has been successfully used for the molecular characterization of sweet cherries (P. avium (L.) L.) and for the tetraploid sour cherry (Cantini et al., 2001, Dirlewanger et al., 2002; Struss et al., 2002; Wünsch and Hormaza, 2002; Clarke and Tobutt, 2003; Vaughan and Russell, 2004; Kacar et al., 2005; Pedersen, 2006; Fernández i Marti et al., 2012; Liu et al., 2018; Muccillo et al., 2019).

It has been shown that the genomes of the diploid Prunus species exhibit a high degree of synteny and that they exhibit chromosome collinearity (Shirasawa et al., 2017; Wang et al., 2020), and so the microsatellite markers developed from different species are theoretically useful to develop genetic studies in any Prunus species.

The aim of this study was to perform a molecular characterization of sweet cherry cultivars grown in Chile, defining a minimal set of microsatellite markers able to differentiate sweet cherry cultivars in a trustable fashion. The results presented here are the basis for the development of a fingerprinting protocol for the unequivocal identification of the sweet cherry cultivars grown in Chile.

\section{MATERIALS AND METHODS}

\section{Plant material}

A total of 87 sweet cherry (Prunus avium (L.) L.) cultivars and a wild P. avium seedling selection used as rootstock ('Mazzard F12/1') were used for this study. Three groups of cultivars where included: one group of 49 samples came from a private germplasm collection ("Paine" collection) located at the Metropolitan Region (33⒋'13.4" S, 70 40'02.0" W), Chile. Another group of 19 samples came from another private collection ("Talca" collection), established at the Maule Region (345' $53.9^{\prime \prime}$ S, $\left.71^{\circ} 13^{\prime} 50.7^{\prime \prime} \mathrm{W}\right)$, Chile, which contained mainly cultivars of Hungarian origin. The other 19 cultivars were collected in different regions throughout the Chilean cherry growing area (Table 1).

\section{DNA extraction}

Genomic DNA was extracted from young fresh leaves of each cultivar according to Varas et al. (2013). DNA integrity and concentration were both checked on 1\% (w/v) agarose gels as well as with the Infinite 200 PRO NanoQuant spectrophotometer (Tecan Tradind AG, Männedorf, Switzerland).

\section{Microsatellite markers amplification}

Samples were PCR-amplified using nine microsatellite markers (Table 2). PCR reactions were carried out in a total volume of $12 \mu \mathrm{L}$, with $20 \mathrm{ng}$ genomic DNA, $0.5 \mu \mathrm{M}$ each forward and reverse primers, $0.2 \mathrm{mM}$ dNTPs, $2.5 \mathrm{mM} \mathrm{MgCl}, 2.4 \mu \mathrm{L}$ Colorless GoTaq reaction buffer (5×), and 0.25 U GoTaq DNA polymerase (Promega, Madison, Wisconsin, USA). PCR reactions were carried out on an XP Cycler thermocycler (Bioer Technology, Hi-tech [Binjiang] District Hangzhou, P.R. China) using the following temperature profile: $94{ }^{\circ} \mathrm{C}$ for $5 \mathrm{~min}, 35$ cycles of $94{ }^{\circ} \mathrm{C}(30 \mathrm{~s}), 56{ }^{\circ} \mathrm{C}(30 \mathrm{~s}), 72{ }^{\circ} \mathrm{C}(30 \mathrm{~s})$, and a final extension at $72{ }^{\circ} \mathrm{C}$ for $7 \mathrm{~min}$. Polyacrylamide gel electrophoresis and silver-staining were done as was described by Narváez et al. (2001). Fragment sizes were estimated by comparison with known allelic patterns. 
Table 1. Description of plant material used in this study.

\begin{tabular}{|c|c|c|}
\hline Cultivar/Selection & Parentage (if known) & Origin \\
\hline $71^{1} 9^{1}$ & Unknown & Unknown \\
\hline Aida $^{2}$ & Moldvai fekete $\times$ H-236 (Germersdorfi $\times$ o.p. $)$ & Hungary \\
\hline Alex $^{2}$ & Van $\times$ JI2420 & Hungary \\
\hline Anita $^{2}$ & Trusenszkaja $2 \times$ H-3 (Germersdorfi × o.p.) & Hungary \\
\hline B5 $4^{1}$ & Unknown & Unknown \\
\hline Badacsony $^{3}$ & Unknown & Hungary \\
\hline Benton (Columbia) ${ }^{3}$ & Stella $\times$ Beaulieu & USA \\
\hline Bing $^{1}$ & Black Republican $\times$ Napoleo & USA \\
\hline Bing $874^{1}$ & Unknown & Unknown \\
\hline Black Republican ${ }^{1}$ & Eagle or Napoleon $\times$ Black Tartarian & USA \\
\hline Black Tartarian ${ }^{3}$ & Unknown & England \\
\hline $\mathrm{C} 15^{3}$ & Unknown & Unknown \\
\hline $\mathrm{C} 78^{1}$ & Unknown & Unknown \\
\hline $\mathrm{C} 82^{3}$ & Unknown & USA \\
\hline Carmen $^{2}$ & Sarga Dragan $\times$ H-203 (Germersdorfi $\times$ o.p.) & Hungary \\
\hline Chamichoco $^{3}$ & Unknown & Unknown \\
\hline Checa $9^{1}$ & Unknown & Unknown \\
\hline Chelan $^{3}$ & Stella $\times$ Beaulieu & USA \\
\hline Compact Stella ${ }^{1}$ & Irradiated Stella & Canada \\
\hline Corazón de paloma ${ }^{3}$ & Unknown & Unknown \\
\hline Cristal champagne ${ }^{3}$ & Unknown & USA \\
\hline Duroni $3^{3}$ & Unknown & Italy \\
\hline Early Bing $^{3}$ & Unknown & Unknown \\
\hline Early Burlat $^{1}$ & Unknown & USA \\
\hline Emperor Francis ${ }^{1}$ & Unknown & Austria \\
\hline Enjidel (Bigalise) ${ }^{4}$ & Delbard $\times$ Starking Hardy Giant & France \\
\hline Garnet $^{1}$ & Starking Hardy Giant $\times$ Bing & USA \\
\hline Germersdorfi $3^{2}$ & Unknown & Hungary \\
\hline Giorgia $^{1}$ & ISF $123 \times$ Caccianese & Italy \\
\hline Glenred (Sequoia) ${ }^{1}$ & $($ Bing $\times$ Brooks $) \times$ Tulare & USA \\
\hline Grace Star ${ }^{1}$ & Burlat $\times$ o.p. & Italy \\
\hline Hedelfingen $^{1}$ & Unknown & Germany \\
\hline Karina $^{1}$ & Schneider $\times$ Rube & Germany \\
\hline Katalin $^{2}$ & Germersdorfi $\times$ Podjebrad & Hungary \\
\hline Kavics $^{2}$ & Germersdorfi $\times$ Budakalaszi & Hungary \\
\hline Kordia $(\text { Attika })^{1}$ & Seedling from Techlovice, North Bohemia & Czech Republic \\
\hline Lambert $^{1}$ & Napoleon $\times$ Black Heart & USA \\
\hline Lapins $^{1}$ & Van $\times$ Stella & Canada \\
\hline Late Maria $^{3}$ & Unknown & USA \\
\hline Linda $^{2}$ & Hedelfingen $\times$ Germersdorfi & Hungary \\
\hline Margit $^{2}$ & Germersdorfi × o.p. & Hungary \\
\hline Marvin $(4-70)^{3}$ & Unknown & USA \\
\hline Mazzard F12/14 & Prunus avium selection & England \\
\hline Moreau (Bigarreau) ${ }^{1}$ & Unknown & France \\
\hline $\mathrm{Nadino}^{2}$ & Spansche Knorpel × o.p. & Germany \\
\hline Newstar ${ }^{1}$ & Van $\times$ Stella & Canada \\
\hline NY1495' & Unknown & USA \\
\hline $\mathrm{Pal}^{2}$ & Burlat $\times$ Stella & Hungary \\
\hline Peter $^{2}$ & Burlat $\times$ Stella & Hungary \\
\hline $\mathrm{PG}^{1}$ & Unknown & Unknown \\
\hline Rainier $^{1}$ & Bing $\times$ Van & USA \\
\hline Regina (USPP11530) ${ }^{1}$ & Schneider $\times$ Rube & Germany \\
\hline Reverchon $^{3}$ & Unknown & France \\
\hline Rita $^{2}$ & Trusenszkaja $2 \times$ H-2 (Germersdorfi × o.p.) & Hungary \\
\hline Rivedel (Earlise) ${ }^{1}$ & Starking Hardy Giant $\times$ Burlat & France \\
\hline Royal Dawn $(\mathrm{CE}-14)^{1}$ & Unknown & USA \\
\hline Royal Rainier ${ }^{1}$ & Stella o.p. & USA \\
\hline Ruby $^{1}$ & Starking Hardy Giant $\times$ Bush Tartarian & USA \\
\hline $\mathrm{Sam}^{1}$ & V-160140 (Windsor $\times$ o.p. $) \times$ o.p. & Canada \\
\hline Sandor $^{2}$ & Burlat $\times$ Stella & Hungary \\
\hline Santina $(13 S-5-22)^{1}$ & Stella $\times$ Summit & Canada \\
\hline
\end{tabular}


Continuation Table 1.

\begin{tabular}{|c|c|c|}
\hline Cultivar/Selection & Parentage (if known) & Origin \\
\hline Schmidt $^{1}$ & Schwarze knorpelkirsche $\times$ o.p. & Germany \\
\hline Schneider ${ }^{1}$ & Local cultivar, Guben & Germany \\
\hline Solymari Gombolyu² & Local cultivar, Budavidek & Hungary \\
\hline Sommerset $^{1}$ & Van $\times$ Vic & USA \\
\hline Staccato $(13 \mathrm{~S} 2009)^{4}$ & Sweetheart $\times$ o.p. & Canada \\
\hline Starking Hardy Giant ${ }^{1}$ & Unknown & USA \\
\hline Stella $^{1}$ & Lambert $\times$ JI 2420 & Canada \\
\hline Sumleta (Sonata) ${ }^{1}$ & Lapins $\times 2 \mathrm{~N}-39-5($ Van $\times$ Stella $)$ & Canada \\
\hline Summit $^{1}$ & Van $\times$ Sam & Canada \\
\hline Sunana $^{3}$ & Unknown & USA \\
\hline Sunburst $^{1}$ & Van $\times$ Stella & Canada \\
\hline Sunset (Sunset Bing) ${ }^{1}$ & Mutation of Bing & USA \\
\hline Superior $^{3}$ & Unknown & Unknown \\
\hline Sweet Georgia $^{1}$ & Mutation of Lapins & Australia \\
\hline Sylvia $(4 \mathrm{C} 17-31)^{1}$ & Van $\times$ Sam & Canada \\
\hline Symphony $(13 \mathrm{~S}-25-25)^{1}$ & Lapins $\times$ Bing & Canada \\
\hline Szomolyai Fekete ${ }^{2}$ & Unknown & Hungary \\
\hline Techlovan $^{1}$ & Van $\times$ Kordia & Czech Republic \\
\hline Toyama I ${ }^{4}$ & Unknown & Unknown \\
\hline Tulare $^{1}$ & $($ Bing $\times$ o.p. $) \times$ o.p. & USA \\
\hline Tunde $^{2}$ & Drogans Gelbe $\times$ Burlat & Hungary \\
\hline Utah Giant $^{1}$ & Unknown & USA \\
\hline Valerij Tschkalov ${ }^{2}$ & Rozornaya (Cherry Rose) × o.p. & Ukraine \\
\hline $\operatorname{Van}^{1}$ & Empress Eugenie $\times$ o.p. & Canada \\
\hline Van Compact ${ }^{1}$ & Irradiated Van & Unknown \\
\hline Vanda $^{1}$ & Van $\times$ Kordia & Czech Republic \\
\hline Vera $^{2}$ & Ljana $($ Trusenszkaja 6) $\times$ Van & Hungary \\
\hline
\end{tabular}

${ }^{1}$ Cultivars from private germplasm collection located in Paine, Metropolitan Region.

${ }^{2}$ Cultivars from private germplasm collection located in Talca, Maule Region.

${ }^{3}$ Cultivars from private germplasm collection located in Quillota, Valparaiso Region.

${ }^{4}$ Cultivars from diverse origin.

Table 2. Microsatellite primers information, linkage group (LG) and reference.

\begin{tabular}{|c|c|c|c|c|c|c|}
\hline SSR locus & Species & Repeat motif & Primer sequences & LG & $\begin{array}{l}\text { Start position-end } \\
\text { position }^{\mathrm{a}}\end{array}$ & Reference \\
\hline \multirow[t]{2}{*}{ ВРРСТ-026 } & Prunus persica & $(\mathrm{AG}) 8 \mathrm{GG}(\mathrm{AG}) 6$ & ATACCTTTGCCACTTGCG & 5 & $4389437-4389454$ & Dirlewanger et al. (2002) \\
\hline & & & TGAGTTGGAAGAAAACGTAACA & & $4389578-4389557$ & \\
\hline \multirow[t]{2}{*}{ BPPCT-037 } & P.persica & (GA)25 & CATGGAAGAGGATCAAGTGC & 5 & $12306819-12306838$ & Dirlewanger et al. (2002) \\
\hline & & & CTTGAAGGTAGTGCCAAAGC & & $12306963-12306944$ & \\
\hline \multirow[t]{2}{*}{ ВРРСТ-039 } & P.persica & $(\mathrm{GA}) 20$ & ATTACGTACCCTAAAGCTTCTGC & 3 & $6662508-6662529$ & Dirlewanger et al. (2002) \\
\hline & & & GATGTCATGAAGATTGGAGAGG & & $6662654-6662632$ & \\
\hline \multirow[t]{2}{*}{ ВРPCТ-040 } & P.persica & $(\mathrm{GA}) 14$ & ATGAGGACGTGTCTGAATGG & 4 & $6460766-6460785$ & Dirlewanger et al. (2002) \\
\hline & & & AGCCAAACCCCTCTTATACG & & $6460902-6460883$ & \\
\hline \multirow[t]{2}{*}{ PMS-3 } & P. avium & & TGGACTTCACTCATTTCAGAGA & 4 & & Cantini et al. (2001) \\
\hline & & & ACTGCAGAGAATTTCACAACCA & & & \\
\hline \multirow[t]{2}{*}{ PMS-30 } & P. avium & & CTGTCGAAAGTTTGCCTATGC & 3 & & Cantini et al. (2001) \\
\hline & & & ATGAATGCTGTGTACATGAGGC & & & \\
\hline \multirow[t]{2}{*}{ PMS-67 } & P. avium & & AGTCTCTCACAGTCAGTTTCT & 1 & & Cantini et al. (2001) \\
\hline & & & ТТААСТТААССССТСТСССТСС & & & \\
\hline \multirow[t]{2}{*}{ UCD-CH18 } & P. avium & (CT)23 & GATGGAAGGCCAAGGCAAC & 4 & & Struss et al. (2002) \\
\hline & & & AATGTTCCCGGTTATATGC & & & \\
\hline \multirow[t]{2}{*}{ UDP96-001 } & P.persica & (CA)17 & AGTTTGATTTTCTGATGCATCC & 6 & $7055429-7055450$ & Testolin et al. (2000) \\
\hline & & & TGCCATAAGGACCGGTATGT & & $7055550-7055531$ & \\
\hline
\end{tabular}

aPhysical position using the peach genome (Peach v2.0) as reference (Verde et al., 2017). 


\section{Genetic analyses}

The Micro-Checker version 2.2.3 software (van Oosterhout et al., 2004) was used for checking microsatellite null alleles and scoring errors. The Popgene program version 1.32 (Yeh et al., 1999) was used for both genic variation and heterozygosity statistics. To compare the efficiency of the markers in cultivar identification, discrimination power (D), confusion probability $\left(\mathrm{C}_{\mathrm{j}}\right)$ and theoretical number of indistinguishable genotypes $\left(\mathrm{X}_{\mathrm{k}}\right)$ were estimated according to Tessier et al. (1999). The PICcalc program (Nagy et al., 2012) was used to calculate the polymorphic information content (PIC).

\section{Phylogenetic and population structure analyses}

A binary matrix was constructed based on the presence (1) and absence (0) of microsatellite alleles. DARwin version 6.0.17 software (Centre de Coopération Internationale en Recherche Agronomique Pour le Développement [CIRAD], Paris, France; https://darwin.cirad.fr) was used for calculating pairwise genetic distances and for constructing a dissimilarity matrix, which was subjected to cluster analysis using the weighted Neighbor-Joining analyses. Bootstrap support values were calculated over all the loci using 1000 repetitions. In order to identify population structure, microsatellite information was analyzed with the program STRUCTURE v2.3.4 (Evanno et al., 2005). To screen appropriate K-values, values of delta K and optimal K were computed using STRUCTURE Harvester (Earl and vonHoldt, 2012; http://taylor0. biology.ucla.edu/structureHarvester/). Genotypes were subdivided into different populations according to their maximum membership probability among the populations and the membership probabilities threshold of 0.80 .

\section{RESULTS AND DISCUSSION}

\section{Microsatellite informativeness}

A total of 87 sweet cherry cultivars plus a Prunus rootstock ('Mazzard F12/1'), a wild P. avium seedling, were analyzed with nine informative microsatellite markers developed for peach and sweet cherry (Table 2; Figure 1). These markers had been previously selected after evaluating a set of 13 microsatellites on a group of 37 sweet cherry cultivars (results not shown); in addition, this set of markers were used previously in sweet cherry fingerprinting studies (Dirlewanger et al., 2002; Kacar et al., 2005; Pedersen, 2006). Micro-Checker showed no evidences for null alleles, scoring error due to stuttering or allelic dropout at any locus $(\mathrm{P}>0.05)$. The allele size range determined for each microsatellite marker is shown in Table 3.

The statistical parameters obtained for microsatellite markers used in this study are presented in Table 3 . A total of 56 alleles were detected, ranging from 3 in UDP96-001 to 8 in BPPCT-040, PMS-3 and PMS-30, with a mean of 6 alleles per locus. This mean is very similar to the one obtained by both Fernández i Marti et al. (2012) in a set of 99 sweet cherry accessions using seven microsatellite markers (7.0 alleles per locus) and by Liu et al. (2018) in a set of 95 sweet cherry accessions using 10 microsatellite markers (6.1 alleles per locus). On the other hand, the value 6 obtained in this study is higher than that obtained in other sweet cherry studies: 3.7 (Wünsch and Hormaza, 2002; 76 cultivars, nine microsatellites), 3.3 (Clarke and Tobutt, 2003; 14 cultivars, 19 microsatellites) and 4.1 (Kacar et al., 2005; 10 cultivars, nine microsatellites). These differences in information content per marker can be explained by the number of cultivars

Figure 1. Allelic pattern of a group of sweet cherry cultivars for the microsatellite marker PMS-30. Separation of the amplicons was done on a $6 \%$ PAGE-urea gel and bands were revealed by silver staining.

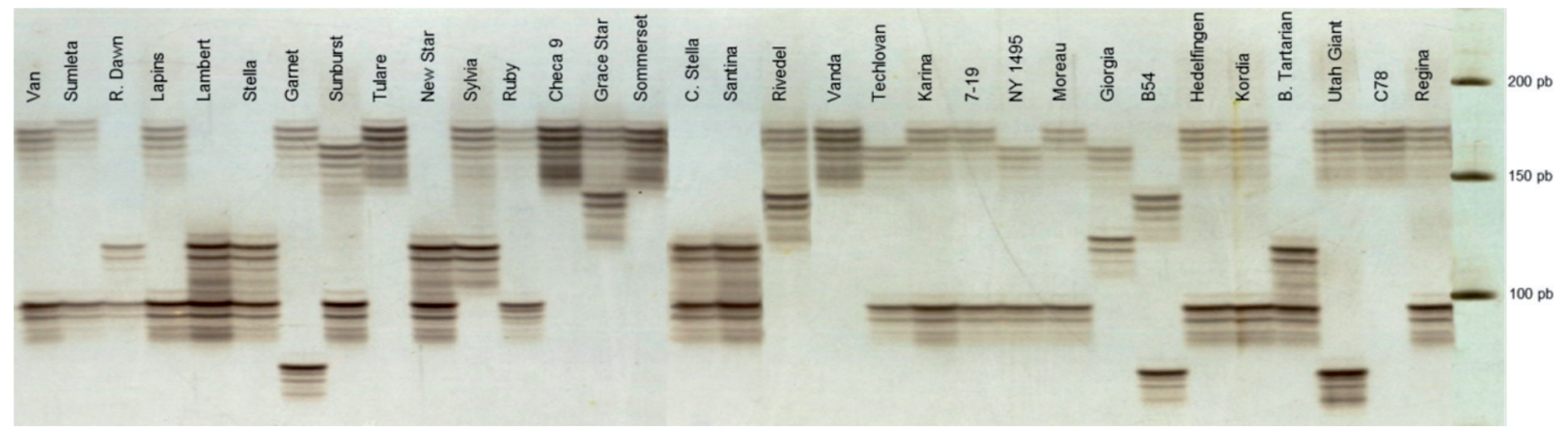


Table 3. Genetic parameters for nine microsatellite markers obtained by analyzing 87 sweet cherry cultivars and a Prunus rootstock.

\begin{tabular}{|c|c|c|c|c|c|c|c|c|c|c|}
\hline $\begin{array}{l}\text { Microsatellite } \\
\text { marker }\end{array}$ & $\mathrm{N}$ & A & $\mathrm{H}_{\mathrm{o}}$ & $\mathrm{H}_{\mathrm{e}}$ & $\mathrm{F}$ & $\mathrm{PIC}$ & $\begin{array}{l}\text { Allele size } \\
\text { range (bp) }\end{array}$ & $\mathrm{C}_{\mathrm{j}}$ & D & $\begin{array}{c}\mathrm{Nr} \text { of observed } \\
\text { genotypes }\end{array}$ \\
\hline ВРРСТ-026 & 88 & 7 & 0.74 & 0.72 & -0.02 & 0.68 & $180-222$ & 0.27 & 0.73 & 14 \\
\hline ВРPCТ-037 & 88 & 6 & 0.76 & 0.72 & -0.06 & 0.68 & $150-166$ & 0.27 & 0.73 & 17 \\
\hline ВРРСТ-039 & 88 & 4 & 0.73 & 0.74 & 0.02 & 0.70 & $144-160$ & 0.25 & 0.75 & 11 \\
\hline ВРРСТ-040 & 88 & 8 & 0.89 & 0.78 & -0.13 & 0.75 & $132-158$ & 0.21 & 0.79 & 20 \\
\hline PMS-3 & 88 & 8 & 0.72 & 0.71 & -0.01 & 0.68 & $206-232$ & 0.28 & 0.72 & 18 \\
\hline PMS-30 & 88 & 8 & 0.76 & 0.76 & 0.00 & 0.73 & $158-200$ & 0.23 & 0.77 & 19 \\
\hline PMS-67 & 88 & 6 & 0.80 & 0.67 & -0.19 & 0.61 & $159-189$ & 0.32 & 0.68 & 13 \\
\hline UCD-CH18 & 88 & 6 & 0.85 & 0.76 & -0.12 & 0.73 & $200-218$ & 0.23 & 0.77 & 17 \\
\hline UDP96-001 & 88 & 3 & 0.60 & 0.59 & -0.01 & 0.55 & $122-140$ & 0.39 & 0.61 & 7 \\
\hline Total & 88 & 56 & & & & & & & & \\
\hline Average & & 6 & 0.76 & 0.72 & -0.06 & 0.68 & & & & \\
\hline
\end{tabular}

$\mathrm{N}$ : Number of scored cultivars; A: number of alleles; $\mathrm{H}_{0}$ : observed heterozygosity; $\mathrm{H}_{\mathrm{e}}$ : expected heterozygosity; F: Wright's fixation index; PIC: polymorphism information content; $\mathrm{C}_{\mathrm{j}}$ : confusion probability; $\mathrm{D}$ : discrimination power.

considered in every case, their genetic background and the set of microsatellites used in each study. Microsatellite marker PMS-30 was previously used by Liu et al. (2018) and it was the marker that produced the highest number of alleles, similar to results obtained in this study.

Allele frequencies $\left(\mathrm{p}_{\mathrm{i}}\right)$ ranged from 0.006 to 0.545 , with a mean of 0.141 (Figure 2). From 56 alleles detected, 23 of them were considered rare alleles $\left(\mathrm{p}_{\mathrm{i}} \leq 0.1\right.$ ); this type of allele was observed in every microsatellite used in this work, except for BPPCT-039 and UDP96-001. These rare alleles were detected mainly in Hungarian cultivars such as 'Solymari gombolyu' and 'Katalin', among others, and from the rootstock 'Mazzard F12/1'. Among the markers, BPPCT-039 showed more uniform distribution of alleles, with no particular alleles overrepresented, while most of the markers showed one or two alleles with a largely higher frequency. Only UDP96-001 showed one over-represented allele with the highest value for $\mathrm{p}_{\mathrm{i}}(0.545)$. Rojas et al. (2008) detected 59 alleles when they analyzed a group of 117 peach and nectarine cultivars using nine microsatellite markers, with allele frequency ranging from 0.004 to 0.846 (mean value $=0.152$ ). They observed 41 rare alleles $\left(p_{i} \leq 0.1\right)$ and six alleles with $p_{i} \geq 0.6$, both diminishing severely the heterozygosity of the harboring loci. By contrast, rare alleles detected in this study did not affect severely the overall heterozygosity. The mean observed heterozygosity $\left(\mathrm{H}_{\mathrm{o}}\right)$ was 0.76 (ranging from 0.60 in UDP96-001 to 0.89 in BPPCT-040) and the mean expected heterozygosity $\left(\mathrm{H}_{\mathrm{e}}\right)$ was 0.72 (ranging from 0.59 in UDP96-001 to 0.78 in BPPCT-040) (Table 3). When comparing these results with those obtained by Fernández i Marti et al. (2012) for a similar number of sweet cherry cultivars, the main difference was observed for $\mathrm{H}_{\mathrm{o}}\left(0.44 v s .0 .76\right.$ in this study), while $\mathrm{H}_{\mathrm{e}}$ had a similar value (0.68). Differences for $\mathrm{H}_{\mathrm{o}}$ values between the two studies may be due to the use of Hungarian sweet cherry cultivars and Prunus rootstocks in this study, both of which contributed with a high number of heterozygous genotypes. When expected and observed heterozygosity values were compared with the Wright's fixation index $(F)$, the value was 0 for PMS-30 $\left(\mathrm{H}_{0}=\mathrm{H}_{\mathrm{e}}\right)$ and it was positive for BPPCT-039 $\left(\mathrm{H}_{\mathrm{o}}<\mathrm{H}_{\mathrm{e}}\right)$, while it was negative for all other markers, with a mean value of -0.06 indicating a subtle excess of heterozygosity in the material studied. Similar results were observed by Carrasco et al. (2012) in Japanese plum, proposing that excess of heterozygosity could be explained by negative assortative mating related to a self-incompatibility system such that parental lines carrying different alleles are favored. The polymorphic information content (PIC) mean value among the microsatellite markers was 0.68 , with a minimum of 0.55 (UDP96-001, the least informative marker in this study) and a maximum of 0.75 (BPPCT-040, the most informative one).

\section{Determination of the optimal microsatellite combination}

With the aim of selecting the optimal combination of microsatellite markers necessary to identify the set of cultivars analyzed in this study, we estimated the risk of confusion using the $C_{j}$ value (confusion probability, or the probability that two randomly chosen individuals from a sample of cultivars have identical banding patterns [Tessier et al., 1999]) of each microsatellite. The discrimination power (D) of each marker represents the probability that two randomly chosen individuals have different patterns and thus are distinguishable from one another, then $\mathrm{D}=1-\mathrm{C}_{\mathrm{j}}$; $\mathrm{D}$ values closest to 1 indicates a higher level of polymorphism or variation. BPPCT-040 presented the highest number of observed 
Figure 2. Allele frequency distribution of nine microsatellite markers in 87 sweet cherry cultivars grown in Chile.
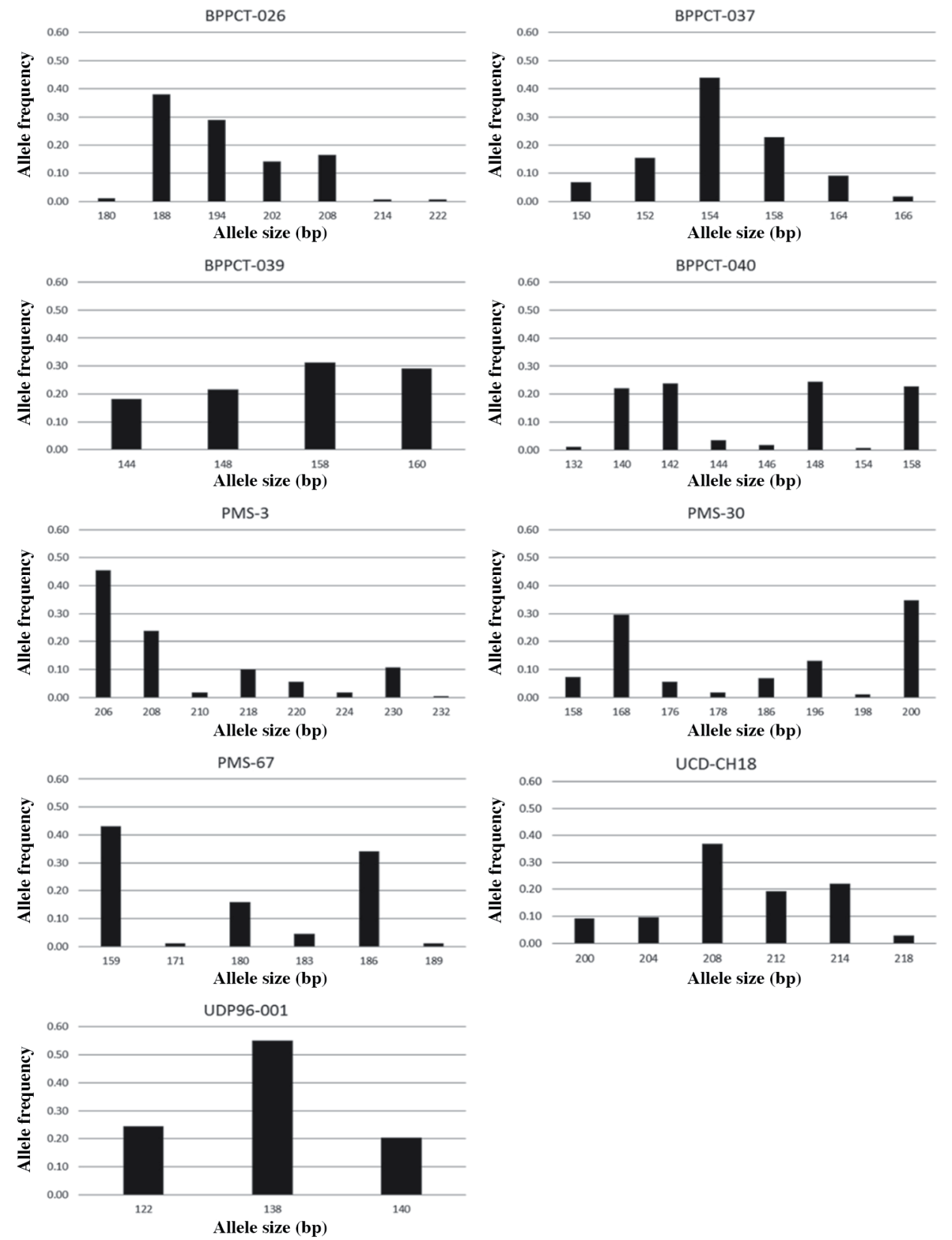

genotypes (20) and the lowest value for $\mathrm{C}_{\mathrm{j}}(0.21)$, while UDP96-001 showed the lowest number of observed genotypes (7) and the highest number of $C_{j}(0.39)$ (Table 3). To determine the optimal microsatellite combination for cultivar identification, microsatellite markers were ranked according to the $\mathrm{C}_{\mathrm{j}}$ value. When using the single marker BPPCT-040, 79 indistinguishable pairs were obtained (Table 4). As new microsatellite markers are added to the analysis, the theoretical number of indistinguishable genotypes $\left(\mathrm{X}_{\mathrm{k}}\right)$ diminishes to finally reach a value of 0 by using the complete set of nine microsatellite. The first two markers were chosen on the basis of their discrimination power (Table 4), but the third marker (BPPCT-039) was selected because it allows differentiating 12 genotypes instead of eight for marker UCD-CH18 when the experimentally observed indistinguishable pairs of genotypes are considered. A similar case was reported by Tessier et al. (1999), when determining the optimal primers combination for the discrimination of a group of 224 cultivars of Vitis vinifera $\mathrm{L}$. The choice of markers was done using the experimental values of the total number of non-differentiated 
Table 4. Selection of the most efficient minimal set of microsatellite markers for identification of 87 sweet cherry cultivars analyzed in this study.

\begin{tabular}{|c|c|c|}
\hline \multirow[b]{2}{*}{ Microsatellite combination } & \multicolumn{2}{|c|}{$\mathrm{Nr}$ of indistinguishable pairs } \\
\hline & $\begin{array}{c}\text { Theoretical } \\
\text { number } \\
\text { (Xk) }\end{array}$ & $\begin{array}{l}\text { Experimentally } \\
\text { observed }\end{array}$ \\
\hline ВРРСТ-040 & 804.0 & 79 \\
\hline ВPРCT-040 + PMS-30 & 184.5 & 40 \\
\hline ВPРCT-040 + PMS-30 + ВРPCT-039 & 46.6 & 32 \\
\hline BPPCT-040 + PMS-30 + BPPCT-039 + UCD-CH18 & 10.8 & 23 \\
\hline ВPРCT-040 + PMS-30 + BPPCT-039 + UCD-CH18 + ВPPCT-037 & 3.0 & 19 \\
\hline ВPРCT-040 + PMS-30 + ВРPCT-039 + UCD-CH18 + ВPРCT-037 + ВРPCT-026 & 0.8 & 19 \\
\hline BPPCT-040 + PMS-30 + BPPCT-039 + UCD-CH18 + BPPCT-037 + BPPCT-026 + PMS-3 & 0.2 & 19 \\
\hline ВРPCT-040 + PMS-30 + ВРPCT-039 + UCD-CH18 + ВРPCT-037 + ВРPCT-026 + PMS-3 + PMS-67 & 0.1 & 19 \\
\hline BPPCT-040 + PMS-30 + BPPCT-039 + UCD-CH18 + BPPCT-037 + ВPPCT-026 + PMS-3 + PMS-67 + UDP96-001 & 0.0 & 19 \\
\hline
\end{tabular}

pairs, instead of the use of $X_{k}$, considering that the efficiency of a primer does not depend on its discrimination power alone, but also on its independence from the set of primers already selected. When the empirical results are analyzed, there was a group of 19 pairs of indistinguishable genotypes, corresponding to $21.6 \%$ of the genotypes analyzed in this study. This number was reached with just the five most informative markers (BPPCT-040, PMS-30, BPPCT-039, UCDCH18 and BPPCT-037). The following pairs or group of genotypes could not be differentiated by any combination of the whole set of nine microsatellite markers tested: 'Lapins'/'Sweet Georgia', 'Schneider'/'Germersdorfi'/'Badacsony', 'Stella'/“Compact Stella', 'Sunana'/'PG', 'Symphony'/‘Staccato'/'Early Bing', 'Van'/'Van Compact', 'Tulare'/“C78', and 'Bing WAB13'/'Bing 260'/'Sunset' (Figure 3). Similar results were observed by Wünsch and Hormaza (2002) and by Fernández i Marti (2012) by using microsatellites for analysis of sweet cherry genotypes derived from mutations of a single genotype. Only the use of single nucleotide polymorphisms (SNP) in the later study, allowed the differentiation of the sport 'Compact Stella' from the original cultivar.

The use of this particular set of microsatellite markers allowed us to differentiate 69 out 88 genotypes (78.4\%) of the analyzed cultivars. Five out of the nine microsatellite markers tested, showed high discrimination power, confirming the high efficiency of this type of marker for cultivar identification. Similar results were obtained by Wünsch and Hormaza (2002), who were able to differentiate 68 sweet cherry cultivars using nine microsatellite markers $(89.5 \%$ of the studied population) and Liu et al. (2018), who completely differentiated 95 sweet cherry accessions using five microsatellite markers (100\% of the studied population). Differentiation of all cultivars analyzed in this study was achieved with the same five microsatellite markers indicated previously, if one representative cultivar of each pair or group of cultivars with the same profile is considered (data not showed).

\section{Sweet cherry diversity}

A Neighbor-Joining dendrogram was constructed to assess the genetic diversity and establish the relationship amongst the sweet cherry accessions based on binary data collected for the nine microsatellite markers tested on the complete set of 88 genotypes (Figure 3). Three clusters were clearly observed and they were consistent with the presumed pedigree-based relationship of the cultivars: Group I included 27 cultivars, most of them from U.S. breeding programs; Group II included 31 cultivars, most of them with European origin; and Group III, included 30 cultivars mainly released by the Summerland Breeding Program in Canada. Using information compiled in Table 1 about pedigree relationships and cultivars origin, grouping was consistent for most of the cultivars. For example, 'Van' and 'Stella' are parent or grandparent of a series of other cultivars analyzed in this study and they appear grouped with most of their relatives in the same group. 'Bing' was grouped closely together with 'Black Republican', its maternal parent, and simultaneously, it was grouped together with 'Rainier', a descendent from the cross of 'Bing' $x$ 'Van'.

When cultivar's origin was considered, 'Duroni 3' and 'Reverchon', that cluster together, where both taken to France from Italy (Wünsch and Hormaza, 2002); while 'Schneider', 'Germersdorfi' and 'Badacsony' that also clustered together, correspond to synonymous denominations of 'Ferrovia', an Italian cultivar spread in Central and Eastern Europe (Palasciano et al., 2006). 'Mazzard F12/1', a cherry rootstock, was grouped with European cultivars, probably because of its origin as a selected seedling at East Malling Research Station of England, which presents uncommon alleles compared to other cultivars in the same group. 
Figure 3. Neighbor-Joining dendrogram of 87 sweet cherry cultivars based on their allelic variation at nine microsatellite loci.

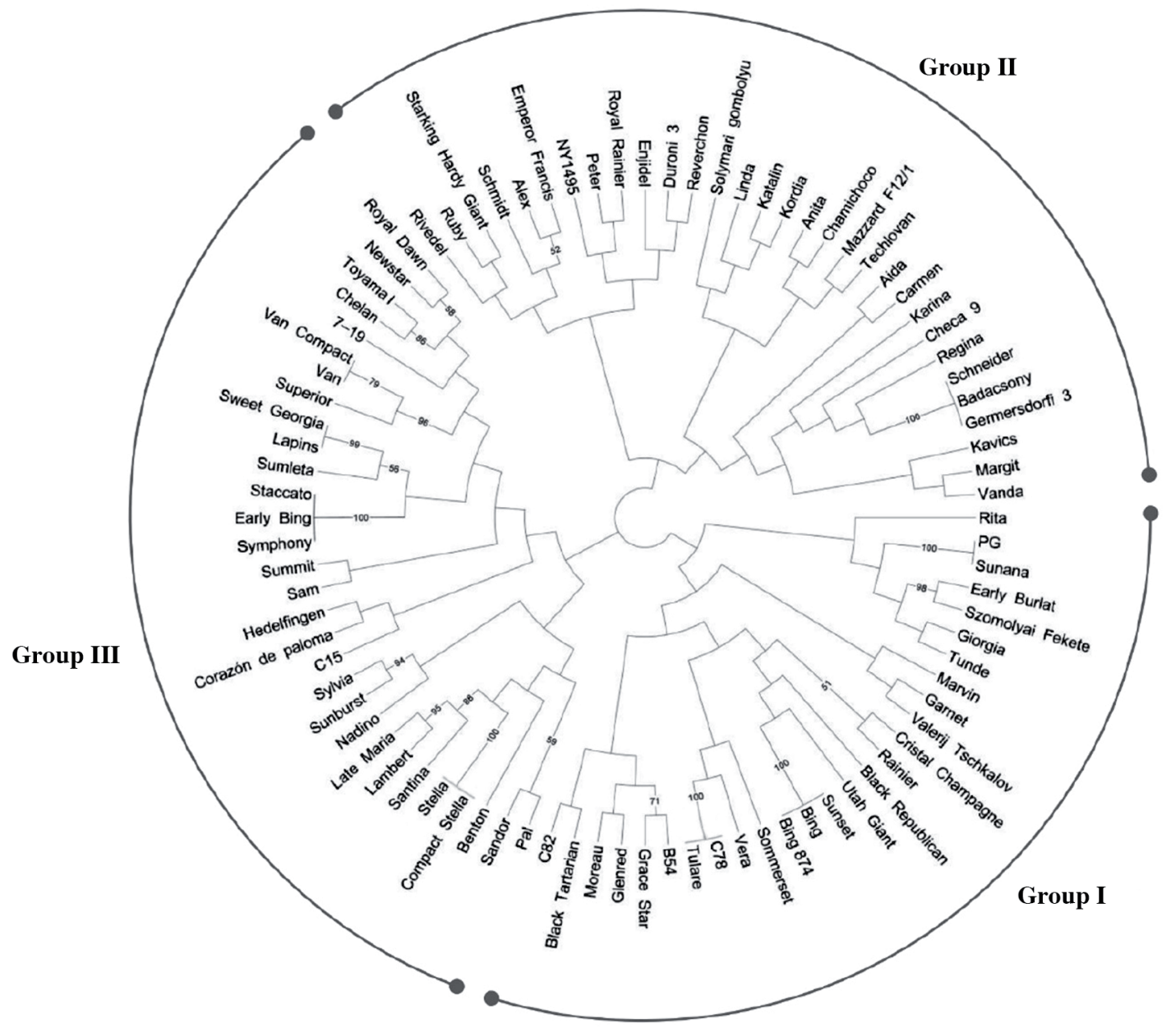

Respect to the cultivars that were not distinguishable using nine microsatellites, they exhibit in the dendrogram a high bootstrap value. 'Symphony', 'Staccato', and 'Early Bing' grouped together, but this is probably a misidentification of the samples, being necessary to use new certified samples from a germplasm repository to confirm their real identity. The pairs of cultivars 'Sunana'/'PG' and 'Tulare'/'C78' may correspond to the original cultivar and one clone with a code, while 'Van'/'Van Compact', 'Stella'/'Compact Stella', 'Lapins'/'Sweet Georgia' and 'Bing WAB13'/'Bing 260'/'Sunset' correspond to somaclonal mutants, or sports, from the original cultivar, respectively. The improbability of differentiating mutants that differ from the original genotype in one or a few genes is expected due to the intrinsic nature of this type of marker, since it is very unlikely that the microsatellite matches the mutated DNA region, considering they have been randomly chosen or selected from the whole genome (Wünsch and Hormaza, 2002). The use of SNPs has been demonstrated as a valuable tool for cultivars fingerprinting (Fernández i Marti et al., 2012), but microsatellite markers have demonstrated their usefulness for fingerprinting, pedigree and genetic analysis in different schemes, and probably they will continue being extensively used for diverse studies in the future.

\section{Population structure analysis}

Population genetic structure among the studied cultivars using STRUCTURE software suggested three populations (maximum $\Delta \mathrm{K}$-value of $\mathrm{K}=3$; Figure $4 \mathrm{~A}$ ). This is in accordance with the three groups found in the phylogenetic analysis (dendrogram in Figure 3). These three populations are shown in Figure 4B. Population I contains 20 cultivars present in Group I and one cultivar ('NY1495') present in Group II. Population II contains 22 cultivars present in Group II, 
Figure 4. Estimation of the population structure for 87 sweet cherry cultivars grown in Chile. (A) Graph showing $\Delta K$ calculated according to STRUCTURE Harvester for the microsatellite dataset; (B) STRUCTURE plot obtained from the microsatellite dataset. The optimal population number was $K=3$. Accessions with colored segments indicate their admixed origin, with a membership probabilities threshold of 0.80 .
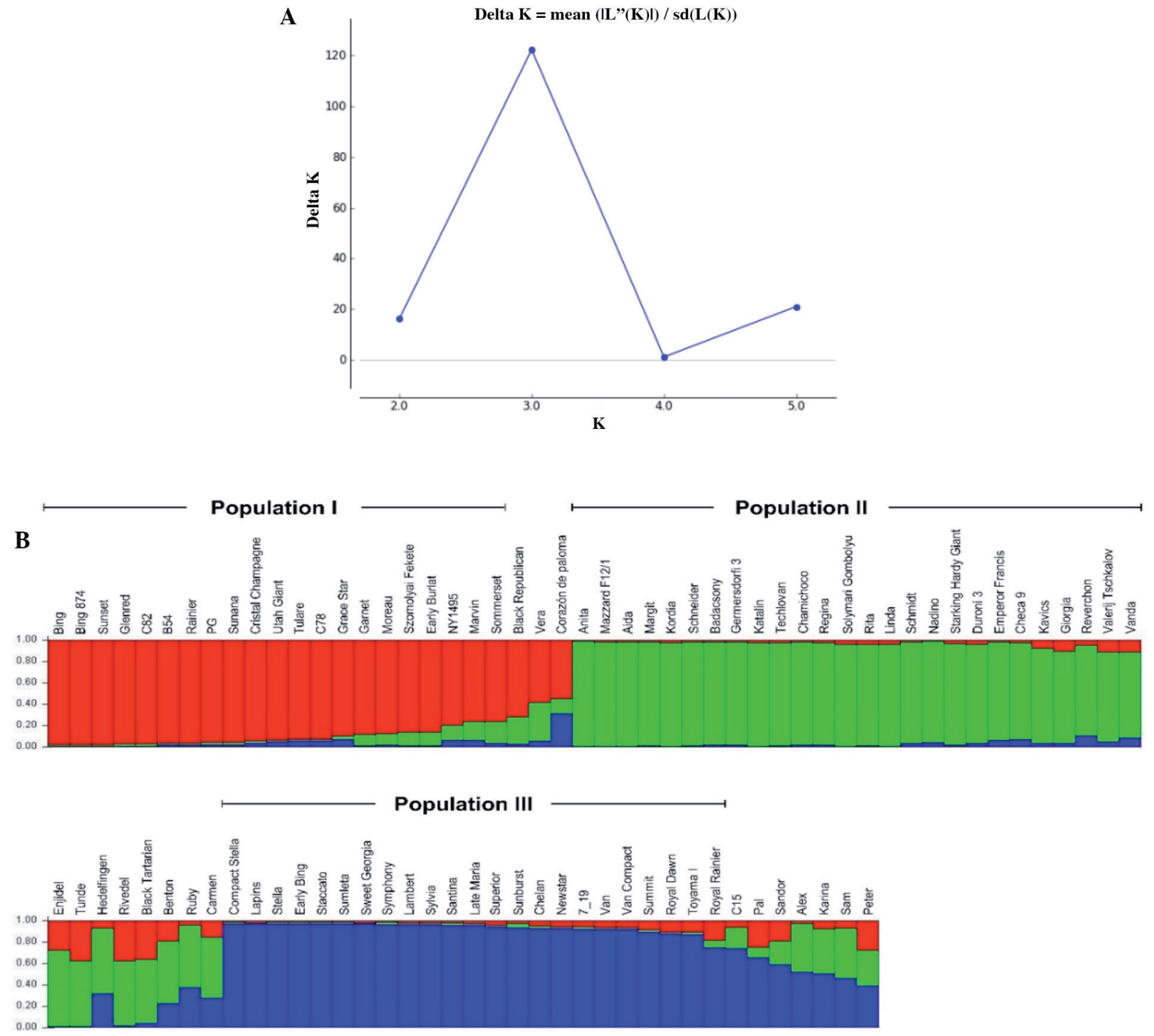

while three cultivars are from Group I ('Giorgia', 'Rita' and 'Valerij Tschkalov') and one is from Group III ('Nadino'). Population III is formed for 22 cultivars from Group III and one cultivar ('Royal Rainier') from Group II. Eighteen cultivars were classified as admixed. These results are substantially in agreement with previous published genetic studies in sweet cherry, where cultivars were grouped based on presumed pedigree-based relationships (Mariette et al., 2010; Fernández i Marti, 2012; Liu et al., 2018).

\section{CONCLUSIONS}

Molecular characterization and the study of genetic diversity of sweet cherry cultivars provide valuable information for germplasm managers such as breeders and industry specialists such as nurseries, growers, distributors and retailers. Our results demonstrated the usefulness of inter-specific transferability of microsatellite markers as a valuable tool for the molecular characterization of sweet cherry cultivars most planted in Chile and elsewhere. The information obtained in 
this study is the basis for developing a fingerprinting protocol using microsatellite markers for cultivars identification, germplasm management and breeding of sweet cherry.

\section{ACKNOWLEDGEMENTS}

This work was funded by the Chilean Comisión Nacional de Investigación Científica y Tecnológica (CONICYT), currently Agencia Nacional de Investigación y Desarrollo (ANID), grants FONDEF D04I-1060 and CONICYT-REGIONAL/ GORE O'HIGGINS/CEAF/R19A10003. We also acknowledge Dr. Lee Meisel from Universidad de Chile who provided sweet cherry DNA samples.

\section{REFERENCES}

Brown, S.K., Iezzoni, A.F., and Fogle, H.W. 1996. Cherries. p. 213-255. In Janick, J., and Moore, J.N. (eds.) Fruit breeding tree and tropical fruits. John Wiley and Sons, New York, USA.

Cantini, C., Iezzoni, A., Lamboy, W., Boritzki, M., and Struss, D. 2001. DNA fingerprinting of tetraploid cherry germplasm using simple sequence repeats. Journal of the American Society for Horticultural Science 126:205-209. doi:10.21273/JASHS.126.2.205.

Carrasco, B., Díaz, C., Moya, M., Gebauer, M., and García-González, R. 2012. Genetic characterization of Japanese plum cultivars (Prunus salicina) using SSR and ISSR molecular markers. Ciencia e Investigación Agraria 39(3):533-543. https://dx.doi.org/10.4067/S0718-16202012000300012.

Choi, C., and Kappel, F. 2004. Inbreeding, coancestry and founding clones of sweet cherries from North America. Journal of the American Society for Horticultural Science 129:535-543. doi:10.21273/JASHS.129.4.0535.

Clarke, J., and Tobutt, K. 2003. Development and characterization of polymorphic microsatellites from Prunus avium 'Napoleon' . Molecular Ecology Notes 3:578-580. doi:10.1046/j.1471-8286.2003.00517.x.

Dirlewanger, E., Cosson, P., Tavaud, M., Aranzana, M.J., Poizat, C., Zanetto, A., et al. 2002. Development of microsatellite markers in peach [Prunus persica (L.) Batsch] and their use in genetic diversity analysis in peach and sweet cherry (Prunus avium L.) Theoretical and Applied Genetics 105:127-138. doi:10.1007/s00122-002-0867-7.

Earl, D.A., and vonHoldt, B.M. 2012. STRUCTURE HARVESTER: a website and program for visualizing STRUCTURE output and implementing the Evanno method. Conservation Genetics Resources 4(2):359-36. doi:10.1007/s12686-011-9548-7.

Evanno, G., Regnaut, S., and Goudet, J. 2005. Detecting the number of clusters of individuals using the software STRUCTURE: a simulation study. Molecular Ecology 14:2611-2620. doi:10.1111/j.1365-294X.2005.02553.x.

Fernández i Marti, A., Athanson, B., Koepke, T., Font i Forcada, C., Dhingra, and Oraguzie, N. 2012. Genetic diversity and relatedness of sweet cherry (Prunus avium L.) cultivars based on single nucleotide polymorphic markers. Frontiers in Plant Science 3:116. doi:10.3389/fpls.2012.00116.

Iezzoni, A., Schmidt, H., and Albertini, A. 1990. Cherries (Prunus). p. 111-173. In Moore, J.N., and Ballington Jr., J.R. (eds.) Genetic resources of temperate fruit and nut crops. Volume 1. International Society for Horticultural Science, Wageningen, The Netherlands.

Iezzoni, A., Wünsch, A., Höfer, M., Giovannini, D., Jensen, M., Quero-García, J., et al. 2017. Biodiversity, germplasm resources and breeding methods. p. 36-59. In Quero-García, J., Iezzoni, A., Pulawska, J., and Lang, G. (eds.) Cherries: Botany, production and uses. CABI, Wallingford, UK.

Kacar, Y.A., Iezzoni, A.F., and Cetiner, M.S. 2005. Sweet cherry cultivar identification by using SSR markers. Journal of Biological Sciences 5:616-619. doi:10.3923/jbs.2005.616.619.

Kalia, R., Rai, M., Kalia, S., Singh, R., and Dhawan, A. 2011. Microsatellite markers: an overview of the recent progress in plants. Euphytica 177:309-334. doi:10.1007/s10681-010-0286-9.

Krmpot, T., Rados, L., and Vokurka, A. Genetic characterisation of autochthonous sweet cherry genotypes (Prunus avium L.) using SSR markers. Genetika 52(1):43-53. https://doi.org/10.2298/GENSR2001043.

Liu, C., Qi, X., Song, L., Li, Y., and Li, M. 2018. Species identification, genetic diversity and population structure of sweet cherry commercial cultivars assessed by SSRs and the gametophytic self-incompatibility locus. Scientia Horticulturae 237:28-35. doi:10.1016/j.scienta.2018.03.063.

Mariette, S., Tavaud, M., Arunyawat, U., Capdeville, G., Millan, M., and Salin, F. 2010. Population structure and genetic bottleneck in sweet cherry estimated with SSRs and the gametophytic self-incompatibility locus. BMC Genetics 11:77. doi:10.1186/1471-2156-11-77.

Muccillo, L., Colantuoni, V., Sciarrillo, R. Baiamonte, G., Salerno, G., Marziano, M., et al. 2019. Molecular and environmental analysis of Campania (Italy) sweet cherry (Prunus avium L.) cultivars for biocultural refugia identification and conservation. Scientific Reports 9:6796. doi:10.1038/s41598-019-43226-2. 
Nagy, S., Poczai, P., Cernák, I., Gorgi A.M., Hegedus, G., and Taller, J. 2012. PICcalc: an online program to calculate polymorphic information content for molecular genetic studies. Biochemical Genetics 50(9-10):670-672 doi:10.1007/s10528-012-9509-1.

Narváez, H.C., Castro M.H., Valenzuela, J., y Hinrichsen, P. 2001. Patrones genéticos de los cultivares de vides de vinificación más comúnmente usados en Chile basados en marcadores de microsatélites. Agricultura Técnica (Chile) 61:249-261. doi:10.4067/S0365-28072001000300001.

Palasciano, M.A., Godini, A., Fanizza, G., Palasciano, M., and Resta, P. 2006. Leading sweet cherry Apulian cv. Ferrovia (Prunus avium L.) appears genetically akin to several central-eastern European cultivars. Proceedings of the $50^{\text {th }}$ Italian Society of Agricultural Genetics Annual Congress, Ischia. 10-14 September. Italian Society of Agricultural Genetics, Portici, Naples, Italy.

Pedersen, B.H. 2006. DNA fingerprints of 51 sweet and sour Prunus accessions using simple sequence repeats. Journal of Horticultural Science and Biotechnology 81:118-124. doi:10.1080/14620316.2006.11512037.

Quero-García, José. 2019. Cherry breeding in the world: current analysis and future perspectives. Italus Hortus 26(1):9-20. doi:10.26353/j.itahort/2019.1.920.

Rojas, G., Méndez, M., Muñoz, C., Lemus, G., and Hinrichsen, P. 2008. Identification of a minimal microsatellite marker panel for the fingerprinting of peach and nectarine cultivars. Electronic Journal of Biotechnology 11(5):4-5.

Ru, S., Main, D., Evans, K., and Peace, C. 2015. Current applications, challenges, and perspectives of marker assisted seedling selection in Rosaceae tree fruit breeding. Tree Genetics \& Genomes 11:8. doi:10.1007/s11295-015-0834-5.

Shirasawa, K., Isuzugawa, K., Ikenaga, M., Saito, Y., Yamamoto, T., Hirakawa, H., et al. 2017. The genome sequence of sweet cherry (Prunus avium) for use in genomics-assisted breeding. DNA Research 24:499-508. doi:10.1093/dnares/dsx020.

Struss, D., Boritzki, M., Karle, R., and Iezzoni, A. 2002. Microsatellite markers differentiate eight Giessen cherry rootstocks. HortScience 37:191-193. doi:10.21273/HORTSCI.37.1.191.

Tessier, C., David, J., This, P., Boursiquot, J.M., and Charrier, A. 1999. Optimization of the choice of molecular markers for varietal identification in Vitis vinifera L. Theoretical and Applied Genetics 98:171-177. doi:10.1007/s001220051054

Testolin, R., Marrazzo, T., Cipriani, G., Quarta, R., Verde, I., Dettori, M., et al. 2000. Microsatellite DNA in peach (Prunus persica $\mathrm{L}$. Batch) and its use in fingerprinting and testing the genetic origin of cultivars. Genome 43:512-520.

van Oosterhout, C., Hutchinson, W.F., Wills, D.P.M., and Shipley, P. 2004. MICRO-CHECKER: software for identifying and correcting genotyping errors in microsatellite data. Molecular Ecology Resources 4:535-538. doi:10.1111/j.1471-8286.2004.00684.x.

Varas, B., Castro, M.H., Rodríguez, R., von Baer, D., Mardones, C., and Hinrichsen, P. 2013. Identification and characterization of microsatellites from calafate (Berberis microphylla, Berberidaceae). Applications in Plant Sciences 1(7):1200003. doi:10.3732/apps.1200003.

Vaughan, S.P., and Russell, K. 2004. Characterization of novel microsatellites and development of multiplex PCR for large-scale population studies in wild cherry, Prunus avium. Molecular Ecology Notes 4:429-431. doi:10.1111/j.1471-8286.2004.00673.x.

Verde, I., Jenkins, J., Dondini, L., Micali, S., Pagliarani, G., Vendramin, E., et al. 2017. The Peach v2. 0 release: high-resolution linkage mapping and deep resequencing improve chromosome-scale assembly and contiguity. BMC Genomics 18(1):1-18.

Wang, J., Liu, W., Zhu, D., Zhu, D., Hong, P., Zhang, S., et al. 2020. Chromosome-scale genome assembly of sweet cherry (Prunus avium L.) cv. Tieton obtained using long-read and Hi-C sequencing. Horticulture Research 7:122. doi:10.1038/s41438-020-00343-8.

Wünsch, A., and Hormaza, J.I. 2002. Molecular characterisation of sweet cherry (Prunus avium L.) genotypes using peach [Prunus persica (L.) Batsch] SSR sequences. Heredity 89:56-63. doi:10.1038/sj.hdy.6800101.

Yaroslav, I., and Volkov, R. 2018. Genetic relatedness of sweet cherry (Prunus avium L.) cultivars from Ukraine determined by microsatellite markers. The Journal of Horticultural Science and Biotechnology 93(1):64-72. doi:10.1080/14620316.2017.1342568.

Yeh, F.C., Yang, R., Boyle, T., Ye, Z., and Mao, J.X. 1999. Popgene, Version 1.32: The user-friendly software for population genetic analysis. Molecular Biology and Biotechnology Centre, University of Alberta, Edmonton, Canada. 